Immune responses during the larval stages of Mytilus galloprovincialis: metamorphosis alters immunocompetence, body shape and behavior.

Pablo Balseiro ${ }^{1}$, Rebeca Moreira ${ }^{1}$, Rubén Chamorro ${ }^{1}$, Antonio Figueras ${ }^{1}$, Beatriz Novoa $^{1 *}$

${ }^{1}$ Instituto de Investigaciones Marinas (IIM), CSIC, C/Eduardo Cabello, 6. C.P.36208

Vigo. Pontevedra, Spain.

Email addresses:

PB: pablobal@iim.csic.es

RM: rebecamoreira@iim.csic.es

RC: ruchaval@iim.csic.es

AF: antoniofigueras@iim.csic.es

BN: beatriznovoa@iim.csic.es

* Corresponding author

Telephone number: (34) 986214463

Fax number: (34) 986292762

e-mail: beatriznovoa@iim.csic.es

Submitted to: Fish \& Shellfish Immunology

\title{
Revised manuscript
}




\section{Abstract}

We investigated the development of the immune system during the larval stages of the mussel Mytilus galloprovincialis. The ability of trochophore and veliger larvae to phagocytose foreign particles (Escherichia coli and zymosan) was measured. Phagocytosis was detected as early as 24 hours post fertilization (hpf) using flow cytometry and fluorescence microscopy. However, although there was a high basal production of reactive oxygen and nitrogen species (ROS and NRS), the phagocytosis of zymosan did not trigger an associated increase in radical production. In addition, a panel of immune-related mussel genes (Myticin B, Myticin C, Mytilin B, Mytimycin precursor 1, Macrophage migration inhibition factor, lysozyme, C1q, membrane attack complex protein and fibrinogen-related protein) was selected for expression profile analysis throughout the different developmental stages (trochophore, veliger, metamorphosis, post-settlement and spat). The expression of these genes increased during the transition from trochophore to spat, and the level of expression was higher in oocytes than in trochophores, suggesting that gene expression during the first larval stages might be maternal in origin. Metamorphosis was identified as a crucial stage when larvae increased the expression of immune-related genes and responded to environmental signals. Whole-mount in situ hybridization studies showed the mantle edge as an important area in the development of immunocompetence in bivalve larvae. Larvae responded to both live and heat-inactivated bacteria by modulating expression of immune-related genes. Altogether, our results support that during the early stages of M. galloprovincialis development, immune mechanisms emerge to aid larvae in managing infections. 


\section{Highlights}

- Mussel larvae phagocytose particles as early as $24 \mathrm{hpf}$.

- There is strong basal reactive radicals production in mussel trochophore larvae.

- Immune-related gene expression is switched on during metamorphosis.

- The mantle edge is associated with immune-related gene expression in veliger larvae.

- $\quad$. anguillarum can modulate larval mussel gene expression.

\section{Keywords}

Larvae, ontogeny, immunocompetence, antimicrobial, metamorphosis, mussel 


\section{Introduction}

Marine invertebrate reproduction generally occurs by the release of a huge number of eggs into the water column and the formation of larvae after egg fertilization. After a period of free living, larvae undergo metamorphosis, transitioning from free-swimming larvae to benthonic postlarva or juveniles [1]. This mechanism ensures the spread of the species throughout nature and can partially explain the rapid colonization of new habitats by marine animals. Embryonic and larval development are important phylogenetic events because bilateral animals are divided into deuterostomes or protostomes based on the embryonic origin of the mouth and anus. Mollusks are lophotrochozoans, a group characterized by the presence of trochophore larvae [2]. The ontogeny of mollusks is a complex process that is only completed by a small percentage of the original larvae produced after fecundation. The main threats to the completion of the larval life cycle are predation and poor environmental conditions, although larvae also have to manage pathogenic infections $[3,4]$.

Among Protostomia, research into larval immune capacity as well as development, genetics and physiology has focused on model species such as the arthropod Drosophila or the nematode Caenorhabditis, which belong to the superphylum Ecdysozoa [5-7], paying less attention to the superphylum Lophotrochozoa, which includes mollusks. Mollusks are an interesting group, not only in terms of aquaculture production [8] but also because they have an important ecological role in the depuration of waters and as environmental sentinels [9]. Additionally, this group includes intermediate hosts for serious parasitic human diseases [10].

Larval settlement and metamorphosis is a vital transition period that is associated with the evolution of metazoans, as well as differentiation and speciation [11]. This stage is also very important because settlement can modify the larval dispersal capacity, leading individuals to settle near their source or to be dispersed with a concomitant mortality risk. Therefore, competent and metamorphosing larvae are important for the ecological and evolutionary success 
of natural populations of marine invertebrates [12]. Even in cultured bivalves, metamorphosis is considered a crucial step for the overall success of the aquaculture facility because animals that have correctly settled usually show increased survival. However, it is unknown if competence is related to the expression of particular genes or if the immune system plays a role in the protection of larval stages. In fact, studies about the gene expression of mollusk larvae during development have been focused mainly on anatomical structural ontogenesis [13, 14], and little is known about bivalve larval immune defense or bivalve response to external stimuli [15-17]. Phagocytosis, antimicrobial peptide production and chemical defenses that serve both to control pathogens and to protect larvae from predation have been proposed as immune mechanisms in veliger larvae [18]. It has been reported that larvae initiate metamorphosis when they are developmentally competent to respond to environmental signals [19-21]; however, the factors that regulate this process have been difficult to identify. In this work, we have focused on the immune competence of several developmental stages of Mytilus galloprovincialis because immune-related genes are essential for responding to external stimuli. We have identified the immune functions occurring at larval stages and profiled gene expression during each developmental stage to understand this complex process.

\section{Materials and Methods}

\subsection{Larval rearing}

Mature Mediterranean mussels (M. galloprovincialis) were obtained from a commercial shellfish farm (Vigo, Northwestern Spain) during the spawning season. Mussels were subjected to mechanical (brush cleaning) and environmental stress (left at least $1 \mathrm{~h}$ without water), and spawning was induced with $1 \mu \mathrm{m}$ filtered seawater (FSW) at $30^{\circ} \mathrm{C}$ containing Isochrysis galbana. The mature animals responding to spawning induction were placed in individual containers and oocyte and sperm quality was observed (bright orange color, cell integrity and sperm motility) under a Nikon Optiphot light microscope (Nikon Instruments Inc., NY, USA). 
Fertilization was performed by mixing high quality oocytes and sperm at a ratio of 1:10 in a sterile glass container containing $2 \mathrm{~L}$ of FSW. After trochophore development for $24 \mathrm{~h}$ at $21^{\circ} \mathrm{C}$, larvae were placed into $150 \mathrm{~L}$ tanks. Larvae were fed with $I$. galbana during the first week post-fertilization and a combination of I. galbana and Phaeodactylum tricornutum after the first week. Samples were taken and observed under a Nikon Eclipse E600 light microscope or a Nikon SMZ800 stereomicroscope. Measures were performed on pictures taken with a DXM1200 operated with ACT-1 v2.70 software (Nikon instruments Inc., NY, USA).

\subsection{Immune stimulation}

Bacterial challenge of larvae was performed with both heat-inactivated and live Vibrio anguillarum at all developmental stages. Larvae were stimulated with $10^{6} \mathrm{CFU} \mathrm{mL}^{-1}$ of either live or inactivated bacterial challenges for $3 \mathrm{~h}$ at $15^{\circ} \mathrm{C}$. Three biological replicates of stimulated larvae or controls were used for each stage. Larvae were concentrated, counted and then distributed into 6-well plates at a final volume of $7 \mathrm{~mL}$ per well.

\subsection{Functional immunology}

The capacity of larvae to phagocytose foreign particles and to produce radical oxygen and nitrogen species was studied from 24 to 72 hours post fertilization (hpf). Briefly, $M$. galloprovincialis larvae were mechanically disaggregated in calcium-magnesium-free saline (CMFS) buffer (137 $\mathrm{mM}$ sodium chloride, $4 \mathrm{mM}$ potassium chloride, $0.4 \mathrm{mM}$ sodium dihydrogen phosphate, $0.2 \mathrm{mM}$ potassium hydrogen phosphate, $12 \mathrm{mM}$ sodium bicarbonate, and $10 \mathrm{mM} \mathrm{D}$-glucose), and the cells were resuspended in FSW prior to flow cytometry experiments.

Phagocytosis assays were performed using the larval cell suspensions and two different fluorescein-labeled (FITC) particles: Escherichia coli or zymosan (Molecular Probes, Life Technologies, Carlsbad, CA, USA). Cells and FITC particles were incubated for 90 min at $17^{\circ} \mathrm{C}$ in the dark and counterstained with trypan blue to quench non-phagocytosed particles. The level of phagocytosis was determined using a FACSCalibur flow cytometer (Becton and Dickinson, 
San Jose, CA, USA). In addition, phagocytosis was also studied with fluorescence microscopy using pHrodo-labeled E. coli and Texas Red-labeled zymosan (Molecular Probes). Whole larvae were incubated with fluorescent particles as explained above and fixed overnight at $4^{\circ} \mathrm{C}$ with 4\% paraformaldehyde (Sigma Chem. Co, St. Louis, MO, USA) in FSW. After fixation, larvae were stained with DAPI to visualize nuclei and mounted with ProLong Gold Antifade Reagent (Life Technologies Carlsbad, CA, USA). Larvae were observed with a Leica TCS SPE confocal microscope (Leica Microsystems GmbH, Wetzlar, Germany).

The production of reactive oxygen species (ROS) was measured with flow cytometry using a 5, 6-chloromethyl-2', 7'-dichlorodihydrofluorescein diacetate probe (CM- $\mathrm{H}_{2} \mathrm{DCFDA}$, Molecular Probes, Life Technologies, Carlsbad, CA, USA). After the probe penetrates the cells, it is oxidized by ROS, producing green fluorescence. Similarly, the production of reactive nitrogen species (RNS) was measured with flow cytometry using the 4-amino-5-methylamino2',7'-difluorofluorescein diacetate (DAF-FM diacetate) probe. In both cases, fluorescence in the FL1 channel was measured after trypan blue counterstaining in a FACSCalibur flow cytometer (Becton and Dickinson, San Jose, CA, USA). Zymosan at $0.1 \mu \mathrm{g} \mathrm{mL}^{-1}$ was used to stimulate the immune response. The DNA-specific stain 7-amino-actinomycin D (7AAD) was used to determine the integrity of cell membranes.

\subsection{Gene expression analysis using quantitative PCR}

Larval gene expression was measured both at basal conditions and in challenged larvae. Each experiment was conducted using three different biological replicates, and each replicate belonged to a different family. For ontogeny studies at basal conditions, larvae were collected, concentrated using nylon mesh and centrifuged. The pellet was resuspended in $500 \mu \mathrm{L}$ of Trizol (Life Technologies Carlsbad, CA, USA), and total RNA extraction and cDNA synthesis were performed using the previously described standard protocols [22]. In the studies of challenged larvae, RNA isolation was performed using the Maxwell 16 LEV Simply RNA Tissue Kit 
(Promega, Madison, WI, USA) following manufacturer's instructions. cDNA was synthesized as previously described.

We examined the expression of several immune-related genes previously described in mussel [23]. The following genes were included in the analysis: the antimicrobial peptides Mytimycin precursor 1, Mytilin B, Myticin B and Myticin C; the putative genes implicated in pathogen recognition, $\mathrm{C} 1 \mathrm{q}$ and Fibrinogen-related protein (FREP); the pore-forming molecule MacP; the inflammatory regulator macrophage inhibition factor and lysozyme. The expression of these immune-related genes was also performed in hemocytes from adult mussels.

Quantitative PCR was performed using the PCR primers summarized in Table 1, which were selected according to qPCR restrictions. Oligo Analyzer 1.0.2 was used to assess dimer and hairpin formation. The efficiency of each primer pair was analyzed with seven serial fivefold dilutions of M. galloprovincialis cDNA and calculated from the slope of the regression line during the quantification cycle and compared to the relative concentration of cDNA [24]. A melting curve analysis was also performed to verify that primer dimers were not amplified. Real-time quantitative PCR was performed in the 7300 Real Time PCR System (Applied Biosystems, Foster City, CA, USA). Reactions were performed using SYBR green PCR master mix (Applied Biosystems, Foster City, CA, USA) at a final volume of $25 \mu \mathrm{L}(0.2 \mu \mathrm{M}$ each primer). The standard cycling conditions were $95^{\circ} \mathrm{C}$ for $10 \mathrm{~min}$, followed by 40 cycles of $95^{\circ} \mathrm{C}$ for $15 \mathrm{~s}$ and $60^{\circ} \mathrm{C}$ for $1 \mathrm{~min}$. All reactions were performed as technical triplicates, and melting curves were analyzed for each reaction. The relative expression levels of the genes were normalized using 18S RNA as a reference gene following the Pfaffl method [24] because it is constitutively expressed and not affected by the challenge.

\subsection{In situ hybridization}

Larvae were fixed overnight at $4^{\circ} \mathrm{C}$ in $4 \%$ PFA, dehydrated through successive methanol dilutions and stored at $-20^{\circ} \mathrm{C}$ until whole-mount in situ hybridization (WISH) was performed. Sense and antisense probes were produced by PCR amplification using standard 
PCR conditions ( 35 cycles, $60^{\circ} \mathrm{C}$ annealing temperature). Primers were designed including Sp6 (sense probe) or T7 (antisense probe) promoter sequences for labeling purposes (Table 2). Probes were purified with Amicon Ultra columns (Millipore Bedford, MA, USA), labeled with the Roche DIG RNA Labeling Kit (SP6/T7) (Roche Diagnostics, Mannheim, Germany), purified with Sigmaspin columns (Sigma Chem. Co, St. Louis, MO, USA) and stored at $-20^{\circ} \mathrm{C}$ until use.

WISH was set up for M. galloprovincialis larvae and performed in 24-well plates with $0.5-1 \mathrm{~mL}$ of the appropriate solution in each well. All steps were performed in 41 - $\mu \mathrm{m}$-diameter mesh hand-made baskets. Larvae stored in methanol were re-hydrated in a methanol/PBS series and permeabilized using Proteinase K (Roche Diagnostics, Mannheim, Germany) at a final concentration of $10 \mathrm{ng} \mathrm{mL} \mathrm{m}^{-1}$ at $37^{\circ} \mathrm{C}$ for $10 \mathrm{~min}$ (trochophores and veliger larvae) or $20 \mathrm{~min}$ (metamorphosis larvae). The hybridization was carried out overnight at $70^{\circ} \mathrm{C}$ with $250-500 \mathrm{ng}$ of the corresponding probe in $1 \mathrm{~mL}$ of hybridization mix $(50 \%$ formamide, $5 \times \mathrm{SSC}, 0.1 \%$ Tween-20, $50 \mathrm{mg} \mathrm{mL} L^{-1}$ heparin and $0.5 \mathrm{mg} \mathrm{mL}^{-1}$ torula yeast tRNA). After washing and preincubation with blocking solution ( $2 \%$ sheep serum and $2 \mathrm{mg} \mathrm{mL}^{-1}$ BSA in PBT), larvae were incubated with alkaline phosphatase-conjugated anti-DIG secondary antibody (1:5000) (Roche Diagnostics, Mannheim, Germany) overnight at $4^{\circ} \mathrm{C}$. After washing and presoaking, larvae were stained with NBT/BCIP (Roche Diagnostics, Mannheim, Germany) at room temperature. Larvae were observed and photographed using a Nikon Eclipse TS100 light microscope with a Nikon DS-Fi1 camera (Nikon Instruments Inc., NY, USA).

\subsection{Statistics}

Phagocytosis was compared using Student's t-test with unequal variances to identify statistically significant differences between the control and treatment groups. The results were expressed as the mean \pm SEM and differences were considered significant at $\mathrm{p}<0.01$. All treatments were assayed in triplicate. Production of radical species was considered significant at $\mathrm{p}<0.05$. 
Gene expression levels were transformed to a $\log 2$ scale before comparison with Student's t-test with equal variances to look for statistical significance between oocytes and different developmental stages (larval basal gene expression) or between stimulated and nonstimulated samples. The results were expressed as the mean \pm SEM and differences were considered significant at $\mathrm{p}<0.05$.

\section{Results and discussion}

\subsection{Larval production and development}

M. galloprovincialis larvae were obtained in the laboratory, and the typical larval stages were observed as previously described (Fig. 1A, B, C) [25] with similar growth rates (Fig. 1D) as those obtained in closed systems with small volumes [26]. This is in agreement with previous data from laboratory culture $[27,28]$, where growth is slower than in hatcheries, that are more appropriate for obtaining larvae with higher survival and growth rates [25].

After $24 \mathrm{~h}$ at $21^{\circ} \mathrm{C}$, the majority of fertilized oocytes develop into trochophore larvae (Fig. 1A) that are motile and characterized by the presence of two ciliar rings and an apical flagellum (Fig. 1A). At 48 h, trochophore larvae transformed into the veliger stage (Fig. 1B) in which motile larvae develop a velum that is enclosed in the primordial shell when resting. After 19 days, the majority of larvae swelled and took an umbonate shape. The pediveliger stage is characterized by the formation of a foot and is the larval stage that fixes to the substratum (Fig. 1C). Fig. 1D summarizes the length of larvae from five different $M$. galloprovincialis families. Larval length is altered by metamorphosis events and changes in form, particularly when larvae become umbonate in shape prior to settlement.

\subsection{Immune capacity of early larval stages}


The phagocytic capacity of mussel larvae during their first hours of development is summarized in the Fig. 2, where the distribution of phagocytosing populations after treatment with the two FITC-labeled particles is represented (Fig. 2A). Phagocytic activity was observed as early as $24 \mathrm{hpf}$, and zymosan was the most phagocytosed particle (Fig. 2B).

Results obtained using flow cytometry were confirmed with fluorescence microscopy at 24 and 48 hpf. At 24 hpf (Fig. 3), phagocytosis of both E. coli and zymosan labeled with pHrodo and Texas-Red, respectively, was observed. Phagocytosis occurred at a higher rate at 48 hpf than at 24 hpf. The early appearance of phagocytosis is in agreement with what has been previously observed in Crassostrea virginica larvae, where two different types of blood cells, SER cells (non-phagocytic cells) and phagocytic cells with intracytoplasmic granules and ameboid processes, were capable of internalizing India ink and observed as early as $24 \mathrm{hpf}$. Phagocytes from oyster larvae were also able to engulf cellular debris and foreign organisms [29, 30]. Phagocytosis could be related to tissue reorganization during development [31], supporting the early appearance of this ability in the larval ontogeny.

Although the production of ROS and NO is considered to be associated with phagocytic processes and has been described in bivalve hemocytes [32-34], we were not able to detect triggering of these activities in larvae after stimulation with zymosan (Fig. 4). Basal levels of both reactive intermediates appeared high (a high percentage of fluorescence larvae were detected after treatment with the H2DCFH-DA or DCF-DA probes) but did not increase after stimulation (data not shown). The functions of ROS and NO are not restricted to immunity [35]. ROS have been implicated in cellular signaling and hematopoiesis in mice [36] and Drosophila [37], and nitric oxide is associated with metamorphosis in several different invertebrates [38, 39]. High NO concentrations seem to block metamorphosis [1, 40], and inhibitors of NO production such as L-NAME can induce metamorphosis of the sea urchin Lytechinus pictus [1]. The lack of modulation of ROS and NO by zymosan in our experiments could be in agreement with these observations and suggests that reactive radical production is tightly regulated during these early developmental stages. 


\subsection{Expression throughout development}

Analysis of the constitutive expression of the selected immune-related genes throughout M. galloprovincialis larval development is summarized in Figs. 5 and 6. In general, the expression of these genes increases during the transition from trochophore larvae to later developmental stages, reaching the maximum in adult hemocytes, specialized cells known to be involved in immune defense [41] with high expression levels of immune-related genes [22, 23, 42, 43]. This increase throughout development might suggest the onset of immune competence, in parallel with larval competence, and the preparation of the mussel planktonic larvae for an adult benthic life. Interestingly, there was a clear shift at the metamorphosis stage: most of the genes had low expression levels related to oocytes and were upregulated as development progressed, a change that persisted in adult hemocytes. This finding suggests that at this stage, animals not only modify their body structure and behavior but also acquire a clear immunocompetence by expressing a complete repertoire of immune-related genes. There were two genes, lysozyme and mytimicin, that showed a different expression pattern, with lower expression in all developmental stages compared with oocytes or hemocytes. This result might indicate maternal inheritance (high expression values in oocytes) probably related to immunoprotection of the progeny, although this phenomenon requires further research. Parental investment in the immunoprotection of offspring has been observed in other mollusks [44], and after development, planktotrophic larvae can begin using a fraction of the energy obtained by active feeding for active transcription. Finally, MacP showed high expression levels in all samples compared to oocyte expression, with an onset of expression observed in mussel veliger larvae, which is in agreement with previous studies [43]. This finding suggests possible involvement of this gene in development, as has been reported in other bivalves for genes with a similar expression pattern, such as the metalloprotease inhibitor from Crassostrea gigas, Cgtimp [45]. The basal expression of immune-related genes was confirmed by the WISH studies

(Fig. 6). The trochophore larvae show a conspicuous staining pattern in which some of the larvae are completely stained, whereas others are not. This discrepancy could be due to 
individual variability at the onset of larval gene expression. During development, the variability among larvae is reduced, with the veliger larvae showing specific staining in the mantle edge. This pattern of expression is very different when compared to the positive control actin, which is expressed in all the mussel cells but was mainly observed in the muscles on the interior of the shell, specially in the veliger stage. However, lysozyme and mytimicin were exceptions to this expression pattern; lysozyme was not detected during the veliger stage, and mytimicin showed very low expression in the velum, further supporting the qPCR results. The majority of gene expression observed in pediveliger larvae stained in a patchy pattern along the mantle edge (Myticin B and C, Mytilin B, MgC1q and Macp), although expression of lysozyme and MIF was observed in the digestive gland, and FREP and mytimycin were expressed through the entire larval body in a pattern similar to the positive control actin.

Mussel larval development is rapid and is driven by energy stored by the oocyte, as well as protein and mRNA of maternal origin. After planktotrophic larvae begin actively feeding, the larvae synthesize their own mRNA and proteins, acquiring competence and preparing the animals to settle down and begin benthic life. This anticipatory pathway allows larvae to complete metamorphosis in a very short time [46]. Larvae in a metamorphic state are weak in terms of defense against predators and likely also against pathogens [47]. At this metamorphic stage, expression levels of immune-related genes were higher than in oocytes, suggesting active immune gene expression in mussel larvae. Previous mollusk ontogeny studies showed that this pattern of gene expression is followed by the expression of several proteins, both immune- and non-immune-related $[45,48,49]$. The upregulation of innate immune-related genes during metamorphosis has been previously reported in Boltenia villosa, highlighting the role of innate immunity during ascidian metamorphosis [50]. The upregulation observed during metamorphosis might simply reflect the maturation of the innate immune system but might also be related to the resorption and reorganization of larval tissues, as well as the larval ability to detect and respond to bacterial settlement cues. 
WISH revealed the individual pattern of immune-related gene expression and provided a more realistic representation of gene expression than qPCR. Although several studies have been published concerning different WISH protocols in bivalves [51-53], to our knowledge, the present work depicts the largest array of gene expression examined by WISH in any mollusk species. Strikingly, several of the immune-related genes analyzed were expressed in the mantle edge (Fig. 6). In C. virginica, the accumulation of non-phagocytosing cells has been observed near the thickened mantle region of the hinge, as well as the presence of mitotic figures [30]. Strong labeling of the veliger mantle edge seen by WISH of the hemocyte-expressed mRNAs Myticin B and C and FREPS [22, 23, 42] suggests that accumulation of hemocytes is occurring in this region during larval stages because these genes are expressed mainly in hemocytes.

\subsection{Modulation of immune expression in challenged larvae}

Immune challenge with heat-inactivated (Fig. 7A) or live $V$. anguillarum (Fig. 7B) induced differential expression of the selected immune-related genes. Stimulation with heatinactivated $V$. anguillarum induced down-regulation of gene expression compared to control larvae for most of the immune-related genes during the planktotrophic stages except for MIF, lysozyme, MacP and FREP in trochophores. In veliger larvae, the expression of immune genes was similar for heat-inactivated and live $V$. anguillarum stimulation, where we observed the down-regulation of all genes examined. It is likely that these larvae invest their energetic resources in fast metabolic development to reach settlement and to develop competence [47]. The modulation observed in $C$. gigas during early stages [45] might be related to differences in habitat (sandy shallow waters for oysters and rough rocky shores for mussels). However, larvae in metamorphosis showed important differences in response to heat-inactivated and live $V$. anguillarum stimulation. Heat-inactivated bacteria induced a mild up-regulation of immunerelated genes, whereas live $V$. anguillarum induced down-regulation of all genes except MMG1 and FREP. This effect was also observed in spat, where heat-inactivated $V$. anguillarum induced up-regulation of all of the studied genes, whereas live $V$. anguillarum induced a decrease in gene expression. This result suggests a mechanism for antimicrobial evasion by live but not 
heat-inactivated $V$. anguillarum, as it has been described for other virulent bacteria such as Vibrio parahaemolyticus [54]. This effect seemed more drastic in larvae, perhaps because of the stress associated with metamorphosis. Our data support that bacterial stimulus can trigger an appropriate immune response in larvae, as previously described for the adult mussels $[55,56]$.

In summary, $M$. galloprovincialis immune capacities arise during mussel development as early as the trochophore stage. At this developmental stage, gene expression has contributions of maternal origin, but stimulation induces the expression of immune-related genes. Gene expression starts to rise after the veliger stage, preparing larvae for settlement. At this stage, the expression of immune-related genes characteristic of hemocytes is localized to the mantle edge. Further research is necessary in order to clarify if the accumulation of hemocytes in the mantle edge arises from hemocyte migration or if this organ could have a role in hematopoiesis. At metamorphosis, there is an important switch in the gene expression pattern, which is more similar to adults when examining both constitutive expression and the response to bacterial stimuli. The upregulation of immune-related genes observed during metamorphosis might reflect the maturation of the innate immune system or the reorganization of larval tissues but also plays an active role in immunity at this stage.

\section{Acknowledgements}

This work was funded by the EU Project REPROSEED (FP7 245119) and European structural funds (FEDER) / Ministerio de Ciencia e Innovación (CSIC08-1E-102). R.M. wishes to acknowledge additional funding from the Spanish MICINN through an FPI Spanish research grant (BES-2009-029765). We want to acknowledge Dr. Alejandro Romero for flow cytometry assistance and Noelia Estévez-Calvar for technical assistance. 


\section{References}

1. Bishop CD, Huggett MJ, Heyland A, Hodin J, Brandhorst BP. Interspecific variation in metamorphic competence in marine invertebrates: the significance for comparative investigations into the timing of metamorphosis. Integr Comp Biol 2006; 46:662-82.

2. Halanych KM. The New View of Animal Phylogeny. Annu Rev Ecol, Evol Syst 2004; $35: 229-56$

3. Eckman JE. Closing the larval loop: linking larval ecology to the population dynamics of marine benthic invertebrates. J Exp Mar Biol Ecol 1996; 200:207-37.

4. Lambert C, Nicolas JL, Cilia V, Corre S. Vibrio pectenicida sp. nov., a pathogen of scallop (Pecten maximus) larvae. Int J Syst Bacteriol 1998; 48:481-7.

5. Shia AK, Glittenberg M, Thompson G, Weber AN, Reichhart JM, Ligoxygakis P. Tolldependent antimicrobial responses in Drosophila larval fat body require Spatzle secreted by haemocytes. J Cell Sci 2009; 122:4505-15.

6. Makki R, Meister M, Pennetier D, Ubeda J-M, Braun A, Daburon V, et al. A Short Receptor Downregulates JAK/STAT Signalling to Control the Drosophila Cellular Immune Response. PLoS Biol 2010; 8:e1000441.

7. Ogawa A, Streit A, Antebi A, Sommer RJ. A Conserved Endocrine Mechanism Controls the Formation of Dauer and Infective Larvae in Nematodes. Curr Biol 2009; 19:67-71.

8. FAO. Fisheries and Aquaculture topics. The State of World Fisheries and Aquaculture (SOFIA). In: Pulvenis J-F, editor. Topics Fact Sheets. Rome (Italy): FAO Fisheries and Aquaculture Department. Food and Agricultural Organization (F.A.O); 2012, p. 150.

9. Wootton EC, Dyrynda EA, Pipe RK, Ratcliffe NA. Comparisons of PAH-induced immunomodulation in three bivalve molluscs. Aquat Toxicol 2003; 65:13-25.

10. Morgan JAT, Dejong RJ, Snyder SD, Mkogi GM, Loker ES. Schistosoma mansoni and Biomphalaria: past history and future trends. Parasitology 2001; 123:211-28. 
11. Degnan SM, Degnan BM. The initiation of metamorphosis as an ancient polyphenic trait and its role in metazoan life-cycle evolution. Phil Trans R Soc B 2010; 365:641-51.

12. Williams EA, Degnan SM. Carry-over effect of larval settlement cue on postlarval gene expression in the marine gastropod Haliotis asinina. Mol Ecol 2009; 18:4434-49.

13. Dyachuk VA, Plotnikov SV, Odintsova NA. Appearance of Muscle Proteins in Ontogenesis of the Mussel Mytilus trossulus (Bivalvia). Russ J Mar Biol/Biol Morya 2005; 31:327-30.

14. Ellis I, Kempf SC. Characterization of the central nervous system and various peripheral innervations during larval development of the oyster Crassostrea virginica. Invertebr Biol $2011 ; 130: 236-50$.

15. Jenny MJ, Warr GW, Ringwood AH, Baltzegar DA, Chapman RW. Regulation of metallothionein genes in the American oyster (Crassostrea virginica): Ontogeny and differential expression in response to different stressors. Gene 2006; 379:156-65.

16. Tirapé A, Bacque C, Brizard R, Vandenbulcke F, Boulo V. Expression of immune-related genes in the oyster Crassostrea gigas during ontogenesis. Dev Comp Immunol 2007; 31:859-73.

17. Montagnani C, Tirape A, Boulo V, Escoubas JM. The two Cg-timp mRNAs expressed in oyster hemocytes are generated by two gene families and differentially expressed during ontogenesis. Dev Comp Immunol 2005; 29:831-9.

18. Dyrynda EA, Pipe RK, Ratcliffe NA. Host defence mechanisms in marine invertebrate larvae. Fish Shellfish Immunol 1995; 5:569-80.

19. Hadfield MG, Carpizo-Ituarte EJ, del Carmen K, Nedved BT. Metamorphic Competence, a Major Adaptive Convergence in Marine Invertebrate Larvae. Am Zool 2001; 41:1123-31.

20. Pawlik JR. Chemical ecology of the settlement of benthic marine invertebrates. Oceanogr Mar Biol Annu Rev 1992; 30:273-335.

21. Degnan BM, Morse DE. Developmental and Morphogenetic Gene Regulation in Haliotis rufescens Larvae at Metamorphosis. Am Zool 1995; 35:391-8.

22. Romero A, Dios S, Poisa-Beiro L, Costa MM, Posada D, Figueras A, et al. Individual sequence variability and functional activities of fibrinogen-related proteins (FREPs) in the 
Mediterranean mussel (Mytilus galloprovincialis) suggest ancient and complex immune recognition models in invertebrates. Dev Comp Immunol 2011; 35:334-44.

23. Balseiro P, Falcó A, Romero A, Dios S, Martínez-López A, Figueras A, et al. Mytilus galloprovincialis Myticin C: A Chemotactic Molecule with Antiviral Activity and Immunoregulatory Properties. PLoS ONE 2011; 6:e23140.

24. Pfaffl MW. A new mathematical model for relative quantification in real-time RT-PCR. Nucleic Acids Res 2001; 29:e45.

25. Ruiz M, Tarifeno E, Llanos-Rivera A, Padget C, Campos B. Temperature effect in the embryonic and larval development of the mussel, Mytilus galloprovincialis (Lamarck, 1819). Rev Biol Mar Oceanogr 2008; 43:51-61.

26. Sánchez-Lazo C, Martínez-Pita I. Effect of temperature on survival, growth and development of Mytilus galloprovincialis larvae. Aquacult Res 2012; 43:1127-33.

27. His E, Robert R, Dinet A. Combined effects of temperature and salinity on fed and starved larvae of the mediterranean mussel Mytilus galloprovincialis and the Japanese oyster Crassostrea gigas. Mar Biol 1989; 100:455-63.

28. Satuito CG, Natoyama K, Yamazaki M, Fusetani N. Larval Development of the Mussel Mytilus edulis galloprovincialis Cultured under Laboratory Conditions. Fish Sci 1994; $60: 65-8$.

29. Elston R. Functional anatomy, histology and ultrastructure of the soft tissues of the larval American oyster, Crassostrea virginica. Proc Natl Shellfish Ass 1980; 70:65-93.

30. Elston R. Functional morphology of the coelomocytes of the larval oysters (Crassostrea virginica and Crassostrea gigas). J Mar Biol Assoc UK 1980; 60:947-57.

31. Vernon PJ, Tang D. Eat-Me: Autophagy, Phagocytosis, and Reactive Oxygen Species Signaling. Antioxid Redox Signal 2012.

32. Prado-Álvarez M, Romero A, Balseiro P, Dios S, Novoa B, Figueras A. Morphological characterization and functional immune response of the carpet shell clam (Ruditapes decussatus) haemocytes after bacterial stimulation. Fish Shellfish Immunol 2012; 32:69-78. 
33. García-García E, Prado-Álvarez M, Novoa B, Figueras A, Rosales C. Immune responses of mussel hemocyte subpopulations are differentially regulated by enzymes of the PI 3-K, PKC, and ERK kinase families. Dev Comp Immunol 2008; 32:637-53.

34. Torreilles J, Guerin MC, Roch P. Peroxidase-release associated with phagocytosis in Mytilus galloprovincialis haemocytes. Dev Comp Immunol 1997; 21:267-75.

35. Sardina JL, López-Ruano G, Sánchez-Sánchez B, Llanillo M, Hernández-Hernández A. Reactive oxygen species: Are they important for haematopoiesis? Crit Rev Oncol/Hematol $2012 ; 81: 257-74$.

36. O'Brien JJ, Spinelli SL, Tober J, Blumberg N, Francis CW, Taubman MB, et al. 15-deoxy$\Delta 12,14-P G J 2$ enhances platelet production from megakaryocytes. Blood 2008; 112:405160.

37. Owusu-Ansah E, Banerjee U. Reactive oxygen species prime Drosophila haematopoietic progenitors for differentiation. Nature 2009; 461:537-41.

38. Kuzin B, Roberts I, Peunova N, Enikolopov G. Nitric Oxide Regulates Cell Proliferation during Drosophila Development. Cell 1996; 87:639-49.

39. Enikolopov G, Banerji J, Kuzin B. Nitric oxide and Drosophila development. Cell Death Differ 1999; 6:956-63.

40. Hodin J. Expanding networks: Signaling components in and a hypothesis for the evolution of metamorphosis. Integr Comp Biol 2006; 46:719-42.

41. Cheng TC. Bivalves. In: Ratcliffe NA, Rowley AF, editors. Invertebrate blood cells. London: Academic Press; 1981, p. 233-300.

42. Mitta G, Vandenbulcke F, Noel T, Romestand B, Beauvillain JC, Salzet M, et al. Differential distribution and defence involvement of antimicrobial peptides in mussel. J Cell Sci 2000; 113 ( Pt 15):2759-69.

43. Estévez-Calvar N, Romero A, Figueras A, Novoa B. Involvement of pore-forming molecules in immune defense and development of the Mediterranean mussel (Mytilus galloprovincialis). Dev Comp Immunol 2011; 35:1017-31. 
44. Hathaway JJM, Adema CM, Stout BA, Mobarak CD, Loker ES. Identification of protein components of egg masses indicates parental investment in immunoprotection of offspring by Biomphalaria glabrata (Gastropoda, Mollusca). Dev Comp Immunol 2010; 34:425-35.

45. Tirape A, Bacque C, Brizard R, Vandenbulcke F, Boulo V. Expression of immune-related genes in the oyster Crassostrea gigas during ontogenesis. Dev Comp Immunol 2007; 31:859-73.

46. Jackson D, Leys SP, Hinman VF, Woods R, Lavin MF, Degnan BM. Ecological regulation of development: induction of marine invertebrate metamorphosis. Int J Dev Biol 2002; 46:679-86.

47. Hadfield MG. Why and how marine-invertebrate larvae metamorphose so fast. Semin Cell Dev Biol 2000; 11:437-43.

48. Zhou Z, Wang L, Shi X, Yue F, Wang M, Zhang H, et al. The expression of dopa decarboxylase and dopamine beta hydroxylase and their responding to bacterial challenge during the ontogenesis of scallop Chlamys farreri. Fish Shellfish Immunol 2012; 33:67-74.

49. Ge H, Wang G, Zhang L, Zhang Z, Wang S, Zou Z, et al. Molecular cloning and expression of interleukin-1 receptor-associated kinase 4, an important mediator of Toll-like receptor signal pathway, from small abalone Haliotis diversicolor. Fish Shellfish Immunol 2011; $30: 1138-46$.

50. Davidson B, Swalla BJ. A molecular analysis of ascidian metamorphosis reveals activation of an innate immune response. Development 2002; 129:4739-51.

51. Andersen $\varnothing$, Torgersen J, Pagander H, Magnesen T, Johnston I. Gene expression analyses of essential catch factors in the smooth and striated adductor muscles of larval, juvenile and adult great scallop (Pecten maximus). J Muscle Res Cell Motil 2009; 30:233-42.

52. Fabioux C, Huvet A, Lelong C, Robert R, Pouvreau S, Daniel JY, et al. Oyster vasa-like gene as a marker of the germline cell development in Crassostrea gigas. Biochem Biophys Res Commun 2004; 320:592-8. 
53. Wang X, Liu B, Xiang J. Cloning, characterization and expression of ferritin subunit from clam Meretrix meretrix in different larval stages. Comp Biochem Physiol B Biochem Mol Biol 2009; 154:12-6.

54. Rahman MM, McFadden G. Modulation of NF- $\mathrm{BB}$ signalling by microbial pathogens. Nat Rev Micro 2011; 9:291-306.

55. Li H, Venier P, Prado-Álvarez M, Gestal C, Toubiana M, Quartesan R, et al. Expression of Mytilus immune genes in response to experimental challenges varied according to the site of collection. Fish Shellfish Immunol 2010; 28:640-8.

56. Costa MM, Prado-Álvarez M, Gestal C, Li H, Roch P, Novoa B, et al. Functional and molecular immune response of Mediterranean mussel (Mytilus galloprovincialis) haemocytes against pathogen-associated molecular patterns and bacteria. Fish Shellfish Immunol 2009; 26:515-23.

57. Mitta G, Hubert F, Dyrynda EA, Boudry P, Roch P. Mytilin B and MGD2, two antimicrobial peptides of marine mussels: gene structure and expression analysis. Dev Comp Immunol 2000; 24:381-93. 


\section{Tables}

Table 1: Immune-related genes. Immune-related genes analyzed in the present work and primer sequences used for qPCR. The main function of each gene is also summarized.

\begin{tabular}{|c|c|c|c|c|}
\hline Gene & Putative function & Primer Name & Sequence $\left(5^{\prime}>3^{\prime}\right)$ & Reference \\
\hline \multirow{2}{*}{ Myticin C } & \multirow{2}{*}{$\begin{array}{l}\text { Antimicrobial } \\
\text { peptide }\end{array}$} & Myt $C f w$ & ATTTGCTACTGCCTTCATTG & \multirow{2}{*}[23]{} \\
\hline & & Myt Crv & TCCATCTCGTTGTTCTTGTC & \\
\hline \multirow{2}{*}{$\begin{array}{c}\text { Mytimicin Precursor } \\
1\end{array}$} & \multirow{2}{*}{$\begin{array}{l}\text { Antimicrobial } \\
\text { peptide }\end{array}$} & $\begin{array}{c}\text { MMG1 Mytimycin Prec } \\
\text { qPCRIS }\end{array}$ & ACGGATGACGCTTTTGTTTG & \multirow{2}{*}[23]{} \\
\hline & & $\begin{array}{c}\text { MMG1 Mytimycin Prec } \\
\text { qPCRI As }\end{array}$ & GCAGTCCCAGCAATGTTTC & \\
\hline \multirow{2}{*}{$\begin{array}{c}\text { Macrophage } \\
\text { inhibition factor }\end{array}$} & \multirow{2}{*}{$\begin{array}{l}\text { Inflammatory } \\
\text { regulator }\end{array}$} & MIF $q P C R 1 S$ & TACACCCAGACCAAATGATG & \multirow{2}{*}[23]{} \\
\hline & & MIF $q P C R 1 A s$ & TTCTCCTAATGCTCCAATACTG & \\
\hline \multirow{2}{*}{ Myticin B } & \multirow{2}{*}{$\begin{array}{l}\text { Antimicrobial } \\
\text { peptide }\end{array}$} & Myticin B qPCR $1 S$ & AATGTCTTCGTTGTTCCAG & \multirow{2}{*}[23]{} \\
\hline & & Myticin B qPCR 1 As & AATGCCAGTTTCACCTTG & \\
\hline \multirow{2}{*}{ C1q } & \multirow{2}{*}{ Antigen recognition } & $M g C 1 q q P C R 1 S$ & ATTTATGCGTTCACTTGGAC & \multirow{2}{*}[23]{} \\
\hline & & $M g C 1 q q P C R 1 A s$ & ACACCGATTTTTGTGCTG & \\
\hline \multirow{2}{*}{ Lysozyme } & \multirow{2}{*}{$\begin{array}{l}\text { Bacterial wall } \\
\text { hydrolysis }\end{array}$} & Mg Lysozyme qPCR $1 S$ & TGTCTGTCGCACTATTCTTC & \multirow{2}{*}[23]{} \\
\hline & & Mg Lysozyme qPCR $1 A s$ & AGTCCGCAACAAACATTC & \\
\hline \multirow{2}{*}{ Mytilin B } & \multirow{2}{*}{$\begin{array}{l}\text { Antimicrobial } \\
\text { peptide }\end{array}$} & Myl 4 & TGAAGGCAGGAGTTATTCTGGC & \multirow{2}{*}[57]{} \\
\hline & & Myl 3 & ACAACGAAGACATTTGCAGTAGC & \\
\hline \multirow{2}{*}{$\begin{array}{c}\text { Membrane attack } \\
\text { complex and perforin- } \\
\text { domain-containing } \\
\text { protein (MacP) }\end{array}$} & \multirow{2}{*}{$\begin{array}{l}\text { Pore-forming } \\
\text { molecule }\end{array}$} & Perforin PCRq-F & AAGGTGGATGTTGGTTATGGAGAA & \multirow{2}{*}[23]{} \\
\hline & & Perforin PCRq-R & GCCCAATCAGGCATCATGTTA & \\
\hline \multirow{2}{*}{$\begin{array}{l}\text { Fribinogen-related } \\
\text { protein (FREP) }\end{array}$} & \multirow{2}{*}{ Antigen recognition } & qPCR FREP G1S & GCAAATGTGCTACAAACTACCG & \multirow{2}{*}{ Present work } \\
\hline & & qPCR FREP G1S & TCCAAGTACGCCAGTAAACG & \\
\hline \multirow{2}{*}{$18 \mathrm{~S}$} & \multirow{2}{*}{$\begin{array}{l}\text { Ribosomal } \\
\text { constituent }\end{array}$} & Mussel-18S-F & GTACAAAGGGCAGGGACGTA & \multirow{2}{*}[56]{} \\
\hline & & Mussel-18S-R & CTCCTTCGTGCTAGGGATTG & \\
\hline
\end{tabular}


Table 2. Primer sequences used to synthesize probes and corresponding gene sequences.

Genes and primers uses for probe synthesis. Highlighted bold nucleotides are the Sp6 and T7 promoters.

\begin{tabular}{|c|c|c|}
\hline Gene & Probe & Primer sequence \\
\hline \multirow{2}{*}{ Mytimycin } & Sense-sp6 & ACGATTTAGGTGACACTATAGAAACGGATGACGCTTTTGTTTG \\
\hline & Antisense-T7 & AGTTAATACGACTCACTATAGGGAGCAGTCCCAGCAATGTTTC \\
\hline \multirow{2}{*}{ MIF } & Sense-sp6 & ACGATTTAGGTGACACTATAGAATACACCCAGACCAAATGATG \\
\hline & Antisense-T7 & AGTTAATACGACTCACTATAGGGATTCTCCTAATGCTCCAATACTG \\
\hline \multirow{2}{*}{ Myticin C } & Sense-sp6 & ACGATTTAGGTGACACTATAGAAATATTCCTCAAAACTCAAAACATTCA \\
\hline & Antisense-T7 & AGTTAATACGACTCACTATAGGGATTCAAGCTGAAAACGTCGAA \\
\hline \multirow{2}{*}{ Myticin B } & Sense-sp6 & ACGATTTAGGTGACACTATAGAAAATGTCTTCGTTGTTCCAG \\
\hline & Antisense-T7 & AGTTAATACGACTCACTATAGGGAAATGCCAGTTTCACCTTG \\
\hline \multirow{2}{*}{ Mytilin B } & Sense-sp6 & ACGATTTAGGTGACACTATAGAATGAAGGCAGGAGTTATTCTGGC \\
\hline & Antisense-T7 & AGTTAATACGACTCACTATAGGGAACAACGAAGACATTTGCAGTAGC \\
\hline \multirow{2}{*}{ C1q } & Sense-sp6 & ACGATTTAGGTGACACTATAGAAATTTATGCGTTCACTTGGAC \\
\hline & Antisense-T7 & AGTTAATACGACTCACTATAGGGAACACCGATTTTTGTGCTG \\
\hline \multirow{2}{*}{ Lysozyme } & Sense-sp6 & ACGATTTAGGTGACACTATAGAATGTCTGTCGCACTATTCTTC \\
\hline & Antisense-T7 & AGTTAATACGACTCACTATAGGGAAGTCCGCAACAAACATTC \\
\hline \multirow{2}{*}{ МАСР } & Sense-sp6 & ACGATTTAGGTGACACTATAGAACTATTTGGCGGGAGTTTGAC \\
\hline & Antisense-T7 & AGTTAATACGACTCACTATAGGGATCTGAATCCACAAAGGAGCA \\
\hline \multirow{2}{*}{ FREPs } & Sense-sp6 & ACGATTTAGGTGACACTATAGAAGCAGGTAACAGCATAGAACATC \\
\hline & Antisense-T7 & AGTTAATACGACTCACTATAGGGACCAAGTACGCCAGTAAACG \\
\hline \multirow{2}{*}{ Actin } & Sense-sp6 & ACGATTTAGGTGACACTATAGAA AACCGCCGCTTCTTCATCTTC \\
\hline & Antisense-T7 & AGTTAATACGACTCACTATAGGGA TACCACCAGACAAGACGG \\
\hline
\end{tabular}




\section{Figure Legends}

Figure 1: A. Photomicrographs of Mytilus galloprovincialis. A. Trochophore stage. B. Veliger stage. C. Pediveliger stage. The scale bar for all three micrographs is $50 \mu \mathrm{m}$. D. Mytilus galloprovincialis larval growth throughout development was measured as the mean shell length $\pm \mathrm{SD}$. Dashed bars indicate approximate transition from trochophores to veliger and veliger to pediveliger.

Figure 2: Phagocytosis in Mytilus galloprovincialis larvae. A. Representative dot plot illustration of phagocytosing cells (FL-1 fluorescence events) at $24 \mathrm{hpf}$ according to the cell size (FSC-H) and the cell granularity (SSC-H). The treatments are FSW (C), Escherichia coli (Ec) and zymosan (Zym). B. Phagocytosis is represented as the percentage of fluorescence events (FL-1) for each time and treatment normalized to the control (100\%). The results are presented as the mean of at least two different families and three different technical replicates \pm square error of the mean. Asterisks denote significant differences $(\mathrm{p}<0.01)$.

Figure 3: Microscopic detection of larval phagocytosis. Mussel larvae phagocytosis was examined in complete larvae using pHrodo-labeled Escherichia coli and Texas Red-labeled zymosan. Red fluorescence of labeled particles is shown in columns 1 and 4 for 24 hpf and 48 hpf larvae, respectively. Nuclear DAPI staining and merged images of red and blue fluorescence are also shown in columns 2 and 3 for 24 hpf larvae and columns 5 and 6 for 48 hpf, respectively. Control larvae were treated with FSW. Scale bar is $25 \mu \mathrm{m}$ in all pictures.

Figure 4: Radical production by Mytilus galloprovincialis larvae. A. ROS production after zymosan stimulation in $24 \mathrm{hpf}, 48 \mathrm{hpf}$ or $72 \mathrm{hpf}$ larvae. The results are presented as the percentage of ROS production in the absence of stimulus (100\%) of at least two different mussel families. B. RNS production after zymosan stimulation in $24 \mathrm{hpf}, 48 \mathrm{hpf}$ or $72 \mathrm{hpf}$ larvae. The results are presented as the percentage of RNS production in the absence of stimulus 
$(100 \%)$. The results are presented as the mean \pm square error of the mean for at least two different mussel families, and asterisks denote significantly different treatments $(\mathrm{p}<0.05)$.

Figure 5: Constitutive expression levels of selected immune-related genes throughout different larval stages and in adult hemocytes. Fold change data for each developmental stage related to oocyte expression have been $\log 2$ transformed to facilitate the visual depiction of downregulation. The results are presented as the mean \pm square error of the mean of three different biological replicates. Asterisks indicate significant differences $(\mathrm{p}<0.05)$ in gene expression. Myt C: Myticin C, MMG1: Mytimycin Precursor 1, MIF: Macrophage migration inhibition factor, Myt B: Myticin B, C1q: Complement C1q, Lysozyme, Mytl B: Mytilin B, MACP: Membrane Attack Complex/perforin, FREP: Fibrinogen-related protein.

Figure 6: Whole-mount in situ hybridization of selected immune-related genes throughout different larval stages. Antisense probes for each gene are shown for trochophore, veliger and metamorphosed larvae. The corresponding in situ hybridization using a sense probe for each gene was performed as the negative control, and a representative figure is shown. Actin antisense probe was used as the positive control. Scale bar: $100 \mu \mathrm{m}$.

Figure 7: Modulation of the expression of selected immune-related genes in larval stages challenged with Vibrio anguillarum. Gene expression fold change data for stimulated larvae compared to non-stimulated larvae were $\log 2$ transformed. A. Heat-inactivated Vibrio anguillarum. B. Live Vibrio anguillarum. The results are presented as the mean \pm square error of the mean for three different mussel families performed in triplicate. Asterisks indicate significant differences $(\mathrm{p}<0.05)$ in gene expression. Myt $\mathrm{C}$ : Myticin $\mathrm{C}$, MMG1: Mytimycin Precursor 1, MIF: Macrophage migration inhibition factor, Myt B: myticin B, C1q: Complement C1q, Lysozyme, Mytl B: Mytilin B, MACP: Membrane Attack Complex/perforin, FREP: Fibrinogen-related protein. 


\section{Figures}

Figure 1:

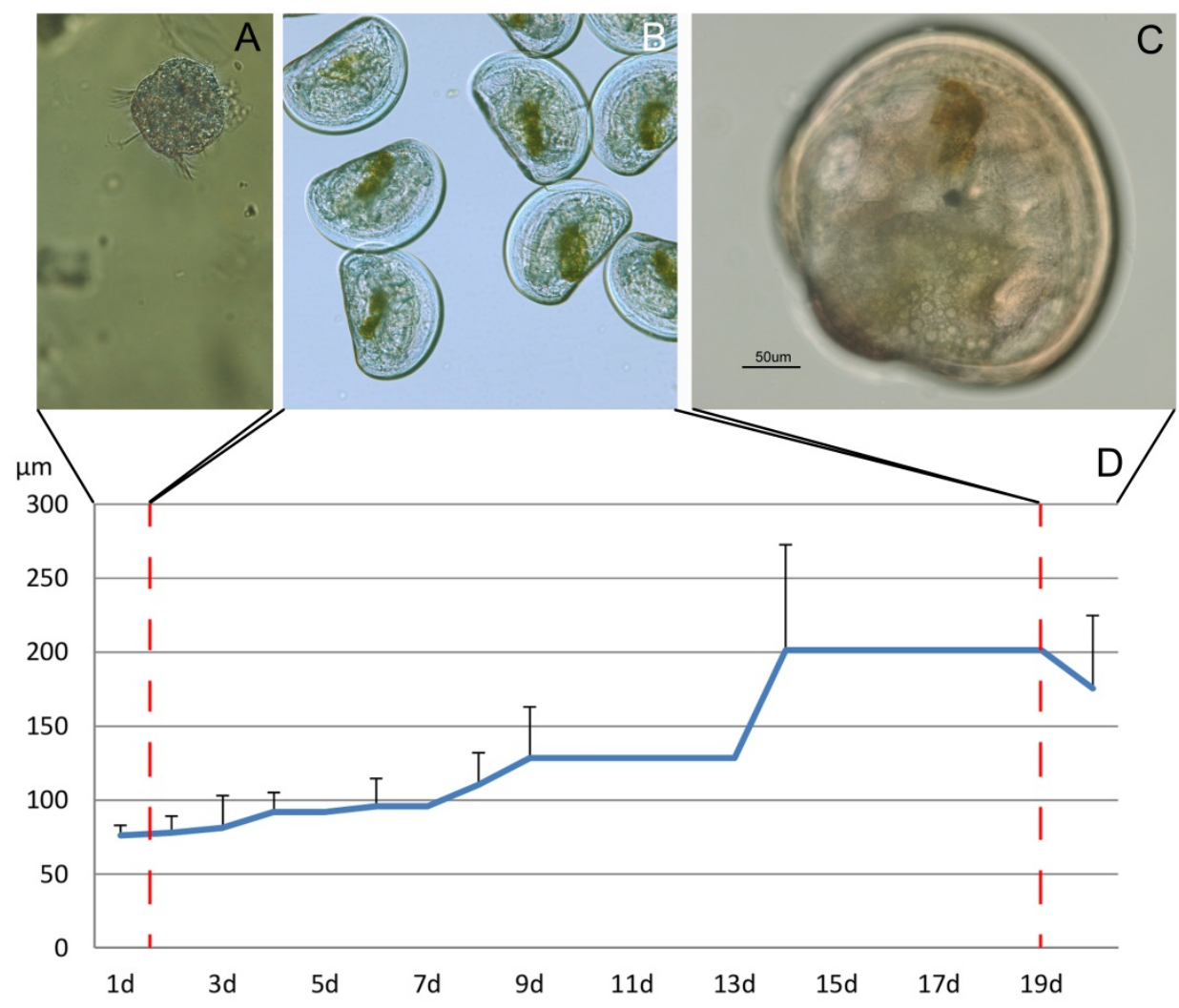


Figure 2:
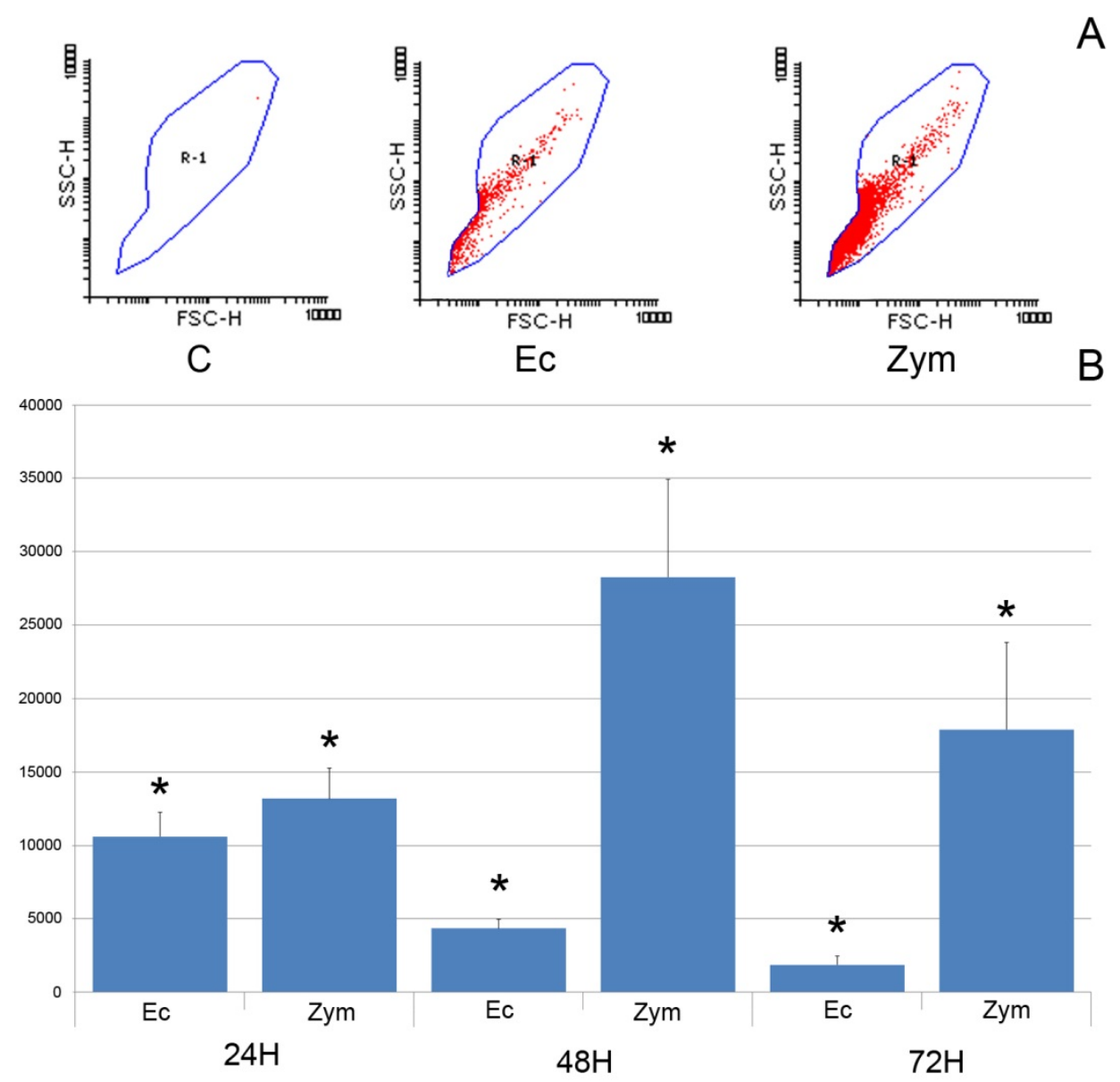
Figure 3:

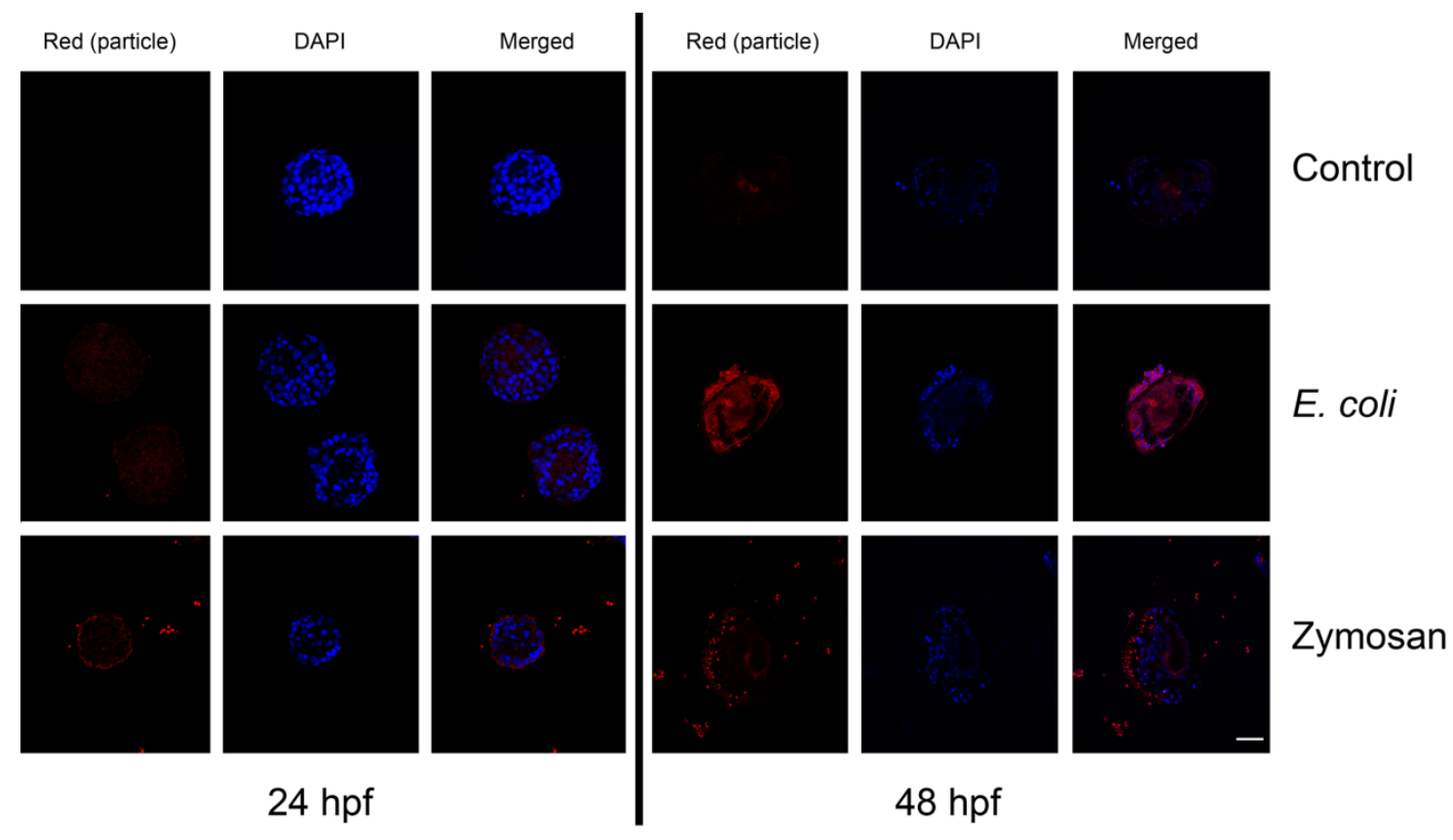


Figure 4

A
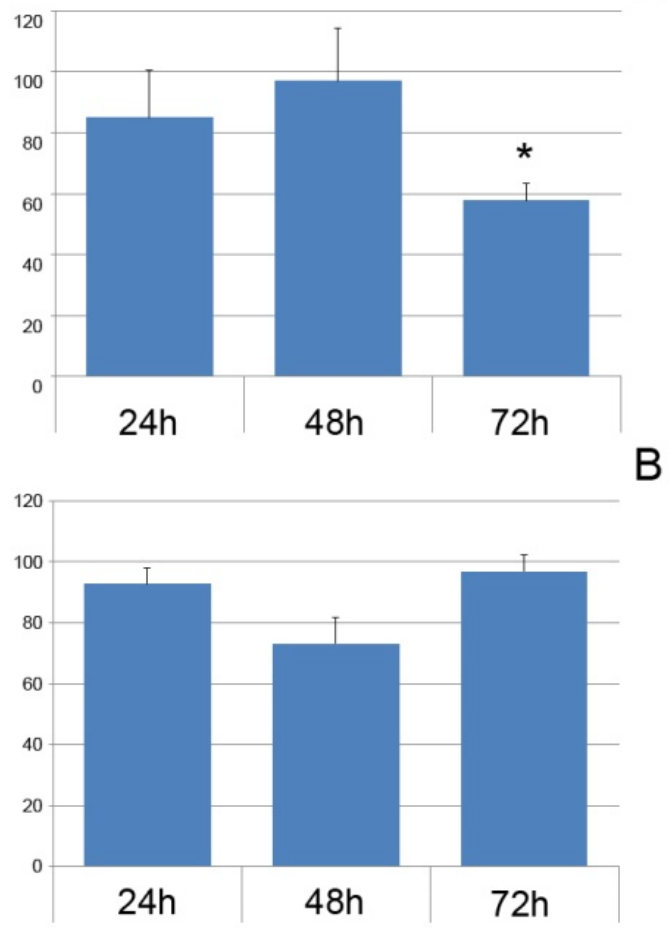
Figure 5:

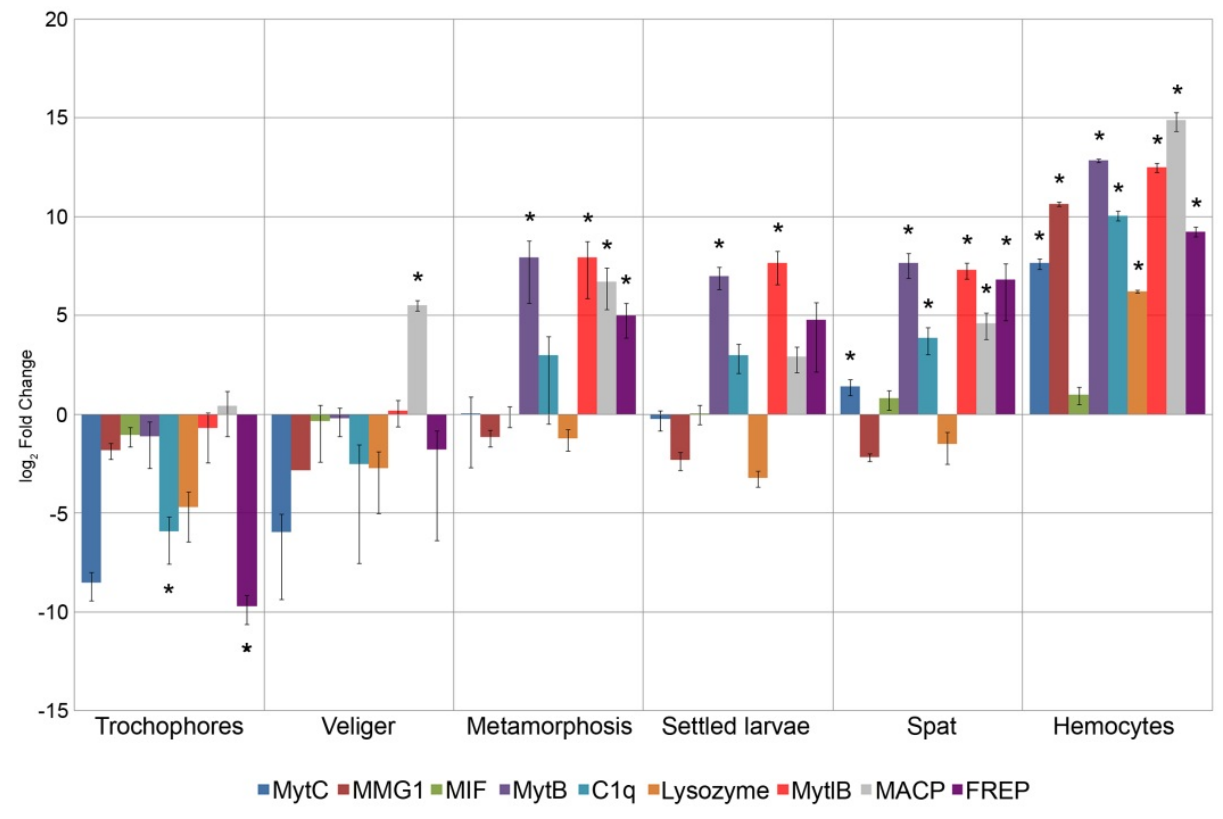


Figure 6:

\begin{tabular}{|c|c|c|c|}
\hline Probes & Trochophores & Veliger & Metamorphosis \\
\hline Mytimycin & & & \\
\hline MIF & & & \\
\hline Myticin C & & & \\
\hline Myticin B & & & \\
\hline Mytilin B & & & \\
\hline C1q & & & \\
\hline Lysozyme & & & \\
\hline MACP & & & \\
\hline FREPS & & & \\
\hline $\begin{array}{c}\text { Negative control } \\
\text { sense probe }\end{array}$ & & & \\
\hline $\begin{array}{c}\text { Positive control: } \\
\text { Actin }\end{array}$ & & & \\
\hline
\end{tabular}


Figure 7:
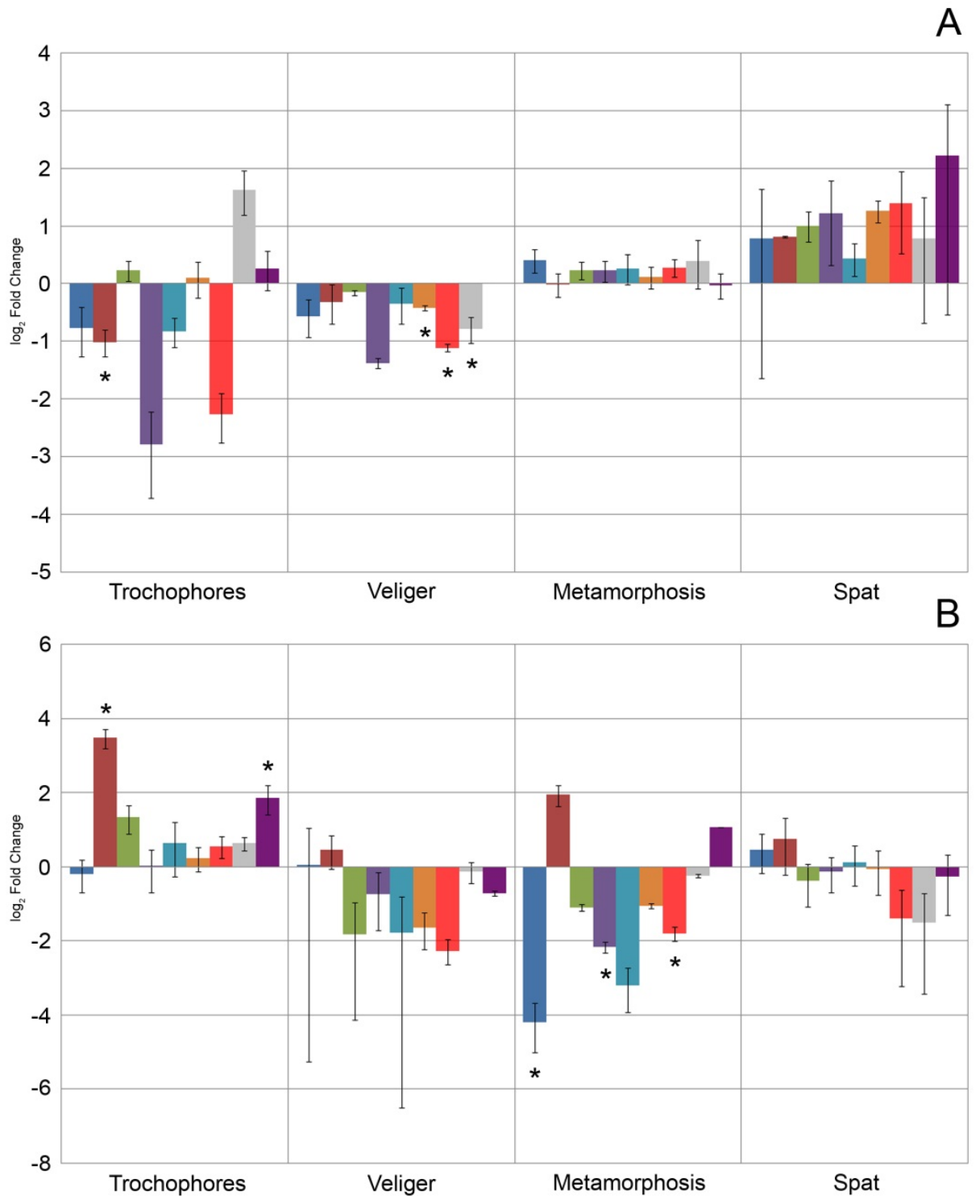

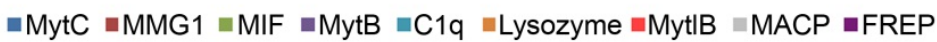

